\title{
Determinism and Gender in Galsworthy's The Man of Property and Naguib Mahfouz's Palace Walk A Naturalistic Approach
}

\author{
Abdulfattah Omar \\ Department of English, College of Science and Humanities, Prince Sattam bin Abdulaziz University, PO box 83, Al-Kharj11943, Saudi Arabia \\ E-mail: a.abdelfattah@psau.edu.sa
}

Received: 18-05-2016

Published: 01-11-2016
Accepted: 30-07-2016

doi:10.7575/aiac.ijalel.v.5n.6p.76
Advance Access Published: September 2016

URL: http://dx.doi.org/10.7575/aiac.ijalel.v.5n.6p.76

\begin{abstract}
This article is concerned with analysing the concepts of determinism and gender in John Galsworthy's The Man of Property and Naguib Mahfouz's Palace Walk from a naturalistic point of view. Determinism is one of the important characteristics of literary naturalism developed by Emile Zola, an eminent French writer, in the second half of the nineteenth century. Analysis indicates that pessimistic determinism, a typical feature of literary naturalism, is represented in the two texts along with other naturalistic features such as conflict, frankness about sexual problems, and objectivity. Analysis also shows that both John Galsworthy and Naguib Mahfouz gave much space in the two novels for women and their problems. Both adopted a naturalist deterministic view of the concept of gender. They used naturalist settings and practices as vehicles for symbolic meanings to convey thematic significance. The notions of determinism and free will as well as the related concepts of fate and nature are central questions in the two texts. The two authors also extend the notion of determinism to gender problems. In the two novels, we see that women are determined to suffer and submit to male dominance and tyranny. Although it is difficult to determine whether the two authors were progressive in adopting an explicit anti-patriarch stance, it can be claimed that Galsworthy and Mahfouz were concerned with introducing the social problems of the age including women problems in an objective way.
\end{abstract}

Keywords: determinism- gender- naturalism- Emile Zola- feminist naturalism

\section{Introduction}

The aim of this study is to explore the authorial treatment of determinism and gender in one period of English and Egyptian prose fiction in literary terms focusing on John Galsworthy's The Man of Property (1906) and Naguib Mahfouz's Bain Al-Qasrain (1956), which is translated into English as Palace walk. Each of the two novels is the first volume within a trilogy that aims at throwing light on the social, political, cultural, and artistic events of the country in a given period. The two trilogies, as critics have pointed out, operate on numerous levels and the setting in each volume is a different part of the city (Allegretto-Diiulio, 2007; Allen, 1995; Asfour, 1993; Beard and Haydar, 1993; Frechet, 1982; Hafez, 2001; Schalit, 1929). The settings illustrate the changes within the English and Egyptian societies (Allen, 1995 ; 2006). Although the two novels were written at different times, they are both concerned with the historical period of World War 1 with its implications on the English and Egyptian life.

The Man of Property is the opening volume of the trilogy Forsyte Saga, which is in many aspects a national epic. Galsworthy's (1922) Forsyte Saga gives one of the most complete and critical pictures that we have of English bourgeois society at the beginning of the 20th century. Here the author deals with contemporary social problems through tracing the life of three generations of the Forsyte family from the eighties of the nineteenth century up to the twenties of the twentieth century. The Man of Property is the most outstanding volume within the family Saga. It is even described as the most popular and probably the best of the score of novels written by John Galsworthy.

Palace Walk is set in Cairo during the years 1917- 1919, the time of the First Egyptian Revolution. The narrative chronicles the British occupation of Egypt and Sudan, which was under the rule of Egypt at that time, in the wake of the British-ordered exile of the Egyptian revolutionary leader Saad Zaghloul, and numerous other members of the Wafd Party. In spite of the political background of the narrative, much of the novel is devoted to the established traditions and customs of family life behind the walls of the house on Palace Walk, one of the historic places in Cairo. The implication here is that the two texts are similar to each other in treating social and family life in all its details which is a good starting point to investigate how each of the two writers treated the concepts of determinism and gender in his novel. In the light of this argument, this study asks the following research questions.

- What literary tradition do the two novels The Man of Property and Palace Walk partake in? And how far does it make sense to classify the two novels as naturalistic novels?

- How is the representation of gender issues conducted in Galsworthy's The Man of Property and Mahfouz's Palace Walk? 
- Can feminist aspects in Galsworthy's The Man of Property and Mahfouz's Palace Walk be interpreted within the naturalistic framework?

In order to answer the research questions, this study adopts the theoretical framework of Zola's (1964) literary naturalism which was originally represented in Le roman experimental (The Experimental Novel, 1880). Literary naturalism describes a type of literature that attempts to apply scientific principles of objectivity to literary texts. The rationale of naturalists is that the techniques and theories of science can be applied in literature to convey a truthful picture of life. According to Becker (1963), naturalism can be simply described as pessimistic materialistic determinism. Feminist aspects in the two novels are studied within the feminist naturalism theoretical framework (Fleissner, 2004; Margraf, 2005; Walker, 1998). The main assumption is that there is a close association between feminism and naturalism (Walker, 1998). The forms of naturalism and the lessons of scientific Darwinism are important for any account of any people including women characters in the world. To put it simply, feminist naturalists propose that the laws that govern the nature can be useful in understanding women characters and their issues in literary works. They believe that there is no contradiction between naturalism and feminism (Fleissner, 2004).

\section{Theoretical background}

Naturalism was first introduced and conceptualized by the French novelist and playwright Emile Zola (1840-1902), who is usually referred to as the major inspiration in pursuing naturalism in literature, by the end of the nineteenth century. Zola (1964) suggested the idea that literature should be experimental. In other words, Zola sought to expand the scope of new scientific theories and introduce Charles Darwin's concepts of evolution and determinism into literature. Eric Margraf (2005: 94) describes this tendency as "the birth of Naturalism from the Spirit of Science". He adds that the term naturalism has been applied to the new tendencies in late nineteenth-century literature "because the literary works of this period regularly conveyed the belief that everything that exists is a part of nature and can be explained by natural and material causes" (2005: 95). In this, Lehan (2006: 47) argues that literary naturalism derives mainly from Darwin's theory of evolution in its emphasis on heredity and environment as a way to explain the nature of reality for the late nineteenth century. Zola (1964) thought that a novelist is like a scientist and that literary imagination should make use of the scientific theory. Zola (1964) explains that literature should observe nature, use social data, and explains the physical world. He adds that literature should reject the supernatural and absolute standards of morality.

From the time of its development, Bell (2012) argues, naturalism was related to realism in one way or another. The common belief is that the naturalists were like the realists in their fidelity to the details of contemporary life, but that they depicted everyday life with a greater sense of the role of such causal forces as heredity and environment in determining behaviour and belief. Many critics even argue that the emergence of naturalism does not mark a radical break with realism (Howard, 1985; Keating, 1971, 1989; Margraf, 2005; Pizer, 1993, 2006). Naturalists went beyond realists by identifying the underlying causes for a person's actions or beliefs. In simple terms, naturalism depicts the relationship between individual and nature, focusing on the characters in their environment and how the fate of the characters is determined by the environment, heredity, chance and/or instinct (Newlin, 2011). Naturalists believe that man is not really free and his life and mortality are controlled by biological, social, economic, and psychological causes. So man is just a victim for internal and external forces that always press him and shape the way of his life. In this, naturalist narratives deal with raw and unpleasant experiences in man's life which reduces him to degrading behaviour in his struggle to survive. Baguley (1990) points out that the characters in naturalist narratives are usually poor, uneducated, unsophisticated and belong to middle and lower classes. It can be thus suggested that naturalism included many aspects of realism. Many critics indeed believe that with the advent and development of naturalism, realism became an integral source of it without losing its own prominence and position. Sandra Woods (1999) describes naturalism as a new realism which can be distinguished from the earlier realism by its focus on the lower classes and its philosophy. Interestingly, Zola himself does not consider naturalism as an independent school of thought. Rather, it is just a movement in philosophical and literary criticism thought.

It was the objectivity and the representation of social problems (which are two distinct features of naturalism) in what came to be called naturalist novels that made critics link naturalism to realism. Lehan (2006) argues that naturalist novelists think that man, controlled by heredity and environment, is the product of his temperament in a social context. The social function of literature cannot be separated from a naturalistic theory of environment. Nelson (2012) argues that at the heart of literary naturalism, there is a belief that literature has a social function. He points out that for Zola and naturalist writers, literature should engage with the 'order of the day' through a representation of the sorts of things that concerned people on a daily basis in their social and individual lives. In naturalist fiction, we can see the implication of industrialization, the growth of the cities, the birth of consumer culture, the hard and difficult condition of the working class, crime, and prostitution. Zola and naturalist novelists were concerned with these issues. In this, they were discussed issues that frequently discussed by the realists. However, they did so in a new way. Joyce (2014) points out that naturalists were mainly concerned with documenting the lives of the lower classes and reflecting upon the ethical problems from a first-hand experience and self-reflection. This leads to the assumption that naturalists produced a very unique and distinct type of realistic fiction.

Most critics, however, agree that the major distinction between realism and naturalism is the particular philosophical orientation of the naturalists (Chase, 1980; Howard, 1985). In this context, Chase (1980) argues that naturalism is essentially realism infused with a pessimistic determinism. Similarly, Becker (1963) considers naturalism as "no more than an emphatic and explicit philosophical position taken by some realists," the position being a "pessimistic materialistic determinism. In naturalist fiction, it was thought that heredity and social conditions, were unavoidable 
determinants in one's life. In naturalist novels, life is usually on its lowest levels and dull. It is not simple as it seems to be. In his book The Theory and Practice of American Literary Naturalism, Donals Pizer (1993: 86) argues that naturalism is pessimistic realism, with a philosophy which sets men in a mechanical world and conceives of them as victimized by that world. In certain conscious exaggerations of naturalism since men are victimized either by outer forces - the milieu or by the inner drives impulses and instincts the naturalist from much brooding is subject to certain temptations.

\section{Determinism in The Man of Property and Palace Walk}

In his portrayal of characters and events, Galsworthy tends to be an objective observer who pays a special attention to the very minute details of the upper-middle class life in late Victorian London. His medium of drawing an overall picture of the English society is the Forsyte family. The characters in Galsworthy's Saga are not free. They do not have the free will to act in the way they wish or like. There are many forces that determine people's lives. The morals of Victorian England, the hypocrisy and social conventions of society, and the marriage codes and laws play a significant role in shaping one's life. And due to these factors, people The Man of Property in are not happy. They lead a pessimistic life. The unhappy marriage of Soames and Irene with its negative implications of all aspects of their personal and family life is deeply rooted in environmental, cultural, religious, social, and political factors: "The Forsytes with their ethics, morals, and principles are presented as unnatural, contradicting human nature and life, and thus doomed to destruction" (Hatif and Asim, 2012: 843). The Forsytes are destined to undergo a pessimistic life.

In The Man of Property, there is no hope for any social reform. Edwards (2011: 201) maintains that the novel was published at a time when reform of the Victorian divorce laws was an increasingly topical issue. According to Kohlke and Gutleben (2011: 6), women were deprived of many of her rights, including divorce. They had to prove adultery in order to obtain divorce. Under these laws, Soames and Irene lived in a permanent limbo. Linda Strahan (2008: 8) argues that "Irene's unhappy marriage to Soames Forsyte has become a metaphor for the plight of women in nineteenth century England before the passage of the Woman's Property Act (1881) and the agitation for further reforms". Hubble (2011) agrees that The Man of Property, which is set in the 1880s, depicts a nation, represented through London that rejects the Victorian ideals and traditions and tries to escape late Victorian London's horrors and darkness. In the Saga, Galsworthy questions the British social order with its Victorian laws and conventions that impose numerous and harsh restrictions on one's life. Although Galsworthy is concerned with representing a real phenomenon of the late nineteenth century London society, there is, however, a tone of sadness that dominates the events of the story. Irene is beautiful but she is passive. She is led from one act to another merely by fate or chance. It is fate and chance that determine her sad fate. This reflects pessimistic determinism that is a characteristic feature of the novel and the saga. In his book The Outline of Literature, John Drinkwater (1923: 1097) argues that the Forsyte Saga reflects Galsworthy's mood of pessimism. In The English and American Estimates of Galsworthy as a Novelist, Elizabeth Watson (1973: 39) argued that The Saga dwells on the misfortunes of man where Galsworthy Illustrates society's crudity and dullness.

According to El- Enany (1993), Naguib Mahfouz intended his trilogy to be a social criticism. In Palace Walk, Mahfouz treats social, political, and religious themes against the background of early twentieth-century Egypt. Similarly, Moosa (1994) argues that Mahfouz portrays the conditions of the poor, oppression of the woman, conflict between generations, rapid rejection of age-old social norms, inefficiency of bureaucracy, growing influence of Western culture, and renunciation of religion among the urban middle class. In this, the novel can be located in the domain of social realism since it is greatly concerned with the relationship between individual and society. In The Arab World: Society, Culture, and State, Barakat (1993: 210) argues that the novels of Naguib Mahfouz portray Egyptian life and society more comprehensively and accurately than the works of all the social scientists put together.

Following the tradition of literary naturalists, Morrissey (1990) argues, Mahfouz portrays the social and political life and illnesses of the age in an objective and realistic way. He presents himself as an objective observer, similar to a scientist taking note of what he sees. Mahfouz's vehicle for his examination of the Cairo society during that period is the family of Al-Sayyid Ahmad Abd Al-Jawad, a middle-class merchant who imposes upon his family - his wife Amina, his three sons and his two daughters -a strict religious regime and directs his own behavior according to his desires and lusts. In spite of the father's tyrannical behavior towards his wife and children, they all obey him out of love, admiration and respect. Although Mahfouz considered objectivity in the discussion of his different themes, a fairly deep-rooted pessimism is often obvious throughout the text. In literary naturalism, writers are usually engendered by their conviction that man is forever at the mercy of forces that he cannot ultimately control: the effects of heredity and/or environment. These forces are often seen to contribute to the downfall of many characters in these novels. People in Palace Walk lead a pessimistic life which they cannot escape for many reasons. It is their fate to be pessimist creatures who cannot change their life for better even though they exert great efforts for doing so. The characters behave in accordance with laws of nature. Instinct and inherited traits drive their actions more than free will.The characters are chained in the fate cycle. That is, they are destined to undergo the hardships and difficulties they experience. This is pessimistic determinism which is a main feature of literary naturalism.

The tone of pessimism that is felt at every part of the action is foregrounded by the feeling of national humiliation due to the British occupation of Egypt. Once Al-Sayyid Ahmad and his eldest son Yasin are caught and humiliated by the British soldiers. They are just representations of the Egyptian people. The implication is that the nation is represented at every stage of the action. Egypt is humiliated by Britain and is destined to suffer under the British colonization. In naturalistic terms, Egypt is governed by forces of nature, heredity, and environment just like man, according to naturalists. The geographic location of Egypt and its natural resources has ever made it subject to attacks from different 
invaders and occupiers. So Egypt, just like man, does not have the free will. It is just a protectorate. Historically, Egypt was declared a British protectorate in 1882 (Sicker, 2001, 101). So the humiliation of Al-Sayyid Ahmad, Yasin, and other Egyptians signifies the humiliation of the nation.

According to Sollars and Jennings (2008: 121), Mahfouz extends his pessimistic view about Egypt in the trilogy. In The Palace of Desire and The Sugar Street, the second and third volumes in the trilogy, "Egypt is not able to be an independent country". There is a pessimistic determinism that Egyptian people are unable to liberate their nation despite brief moments of revolutionary progress. Even in the Sugar Street, the third volume of the Saga, the waves of British colonial oppression continue preventing any hope for the rebirth of the nation. Just like Cairo and Egypt who lead a pessimistic life, the people in the Palace Walk are pessimist. The life of Yasin, the eldest son, for instance, is a good example of pessimistic determinism. Much of his psychological pain and sufferings are due to his mother. His father divorced his mother years ago because she refused to be just a property to Al-Sayyid Ahmad. She did not like the idea that she can be enslaved by her husband. She refuses to be property of her male guardian. This cost her a lot. She lived as a divorced woman in a society where divorced women were looked down by society. Furthermore, her son was taken away from her. So she herself was a victim of the external forces of the society. Her life style afterwards and her so many unequal marriages humiliated Yasin. Many Muslims think that loose women give birth only to bastards and morally corrupt children. In one of his sayings, Prophet Muhammad asks men to consider well the women they are going to marry since ethnic factors are transmitted from mothers to their children. The rationale is that Muslim men should marry only good women since loose women can give birth to morally corrupt children. So it was Yasin's dilemma to be surrounded with his mother's bad reputation. He also inherited his father's lust for women. Later, he fell in love with a dancer, who was his father's mistress, and they got married. So in many ways, Yasin was enforced to lead this pessimistic life. He had no free will in the way of life he had to go.

The life of Yasin can be compared to the life of prostitutes who occupy a great space in the novel. It seems that Mahfouz, in spite of his denials, follows the tradition of Zola who was also concerned with prostitutes in his novels. Emile Zola's Nana published in 1880 describes the career of a French prostitute. In Palace Walk, prostitutes are described as a necessary part of the economy of desire (Mondal, 2003). For biological and heredity reasons, however, they are determined to suffer. Through the character of Jalila, Mahfouz gives an example of a saintly woman which was a stereotypical image of the prostitute during this period. Grace $(2004,22)$ indicates that prostitutes, like wives, were determined to be caught in the web of patriarchal exploitation. Prostitutes suffer because they only because they were born as women. They suffer just like all other women in society. So it is biological considerations that determine their fate. Likewise, Al- Saadawi (1997) argues that life within a male guardian was just a hell for women at this time in Egypt. However, she insists that Mahfouz is just an objective observer of the woman life, either as a "pure mother" or a prostitute and mistress" at this period. She explains that Mahfouz is more concerned with the depiction of the female social condition than stressing the tragedy of the woman at this time. This is again a pure literary naturalist approach to the treatment of social realism where the writer is an objective observer of the social phenomena around him.

It is through Jalila we see that religious and traditional conventions of the society shunt prostitutes to the margins of the society. Although she rejects the religious stereotypes assigned to her, nothing changes. This is a naturalistic belief that in spite of man's efforts to progress, he is destined to fall and die. Although Jalila has so many lovers and her sexuality makes her vital to men, she is not respected by society and no one of her men think of her as a wife. Jalila can expose the men for their hypocritical treatment of the women, but she is still looked upon as a mere body. She is just a body over which he has control and to which he always has access: "No woman was anything more than a body to him" (Naguib Mahfouz. Palace Walk, 2001, 99).

The relationship between Al-Sayyid Ahmad in Palace Walk with prostitutes like Jalila and Zubayda is very similar in many ways to the relationship between Soames and Irene in The Man of Property. Al-Sayyid Ahmad cannot find sexual pleasure or fulfilment with his wife Amina who is completely desexualized because she is a respected woman. So he meets his sexual needs with prostitutes who are very important to him. For Soames, Irene is just a beautiful body. After marriage, Irene discovers that Soames is sexually repellent. When she asks him to sleep in separate bedrooms, he rapes her. This leads us to an important feature in both Palace Walk and The Man of Property. It can be claimed that sexuality is a central feature of the two plots which is also treated in an explicit way. Although sexual frankness was unfamiliar during Mahfouz' age, he offers a detailed depiction of sexual obsessions of father and sons as well as the sinfulness of sexual impulse. Anshuman Mondal (2003: 6) argues that the novels of Cairo Trilogy dwell repeatedly and at length on the female body as an object of sexual desire and almost all male sexual desires, in terms of possessing such sexualized bodies, are satisfied. Mahfouz is explicit in describing the women's bodies even when they are in black garments. Similarly, Galsworthy, unlike Victorian writers, treats sex in a frank, blunt, matter-of fact manner. Frankness about sexuality is one of the characteristics of Zola's writings and literary naturalism. In her book New Women, New Novels: Feminism and Early Modernism, Ann Ardis (1990: 34) argues that truth about sexuality is considered a fundamental characteristic of naturalism which she refers to as a new realism. Sandra Woods agrees that naturalist novelists tended to treat sexual matters in an explicit way where the sexual content is presented frankly and freely. The rationale is that naturalist writers are concerned with the truths as they observe it, not as they like or wish it. Literary naturalism is concerned with analysing facts.

It can be claimed then that the two texts offer a creative vision of reality, in their portrayal of the London and Cairo societies in all details, and in their frankness about sexual problems. In this portrayal, determinism, which is one of the main characteristics of literary naturalism, is a central concept in the two texts. The representation of determinism was 
coloured by a mode of pessimism that dominated the two texts. Other features of literary naturalism are also represented. These include conflict, frankness about sexual issues, and objectivity. It can be concluded that the outlook on determinism and free will found in The Man of Property and Palace Walk is entirely in line with the principles of literary naturalism which are based on the evolutionary theories developed by Charles Darwin in the nineteenth century.

\section{Women and Gender in The Man of Property and Palace Walk}

Gender is one of the main themes in both The Man of Property and Palace Walk. Both John Galsworthy and Naguib Mahfouz dwell into the detailed depiction of women's life during World War 1 period where women were denied many of their rights. In the two texts, there is the image of a husband who has the belief that women are considered objects of property. Numerous analyses have been developed in analysing gender aspects in the two novels. This study, however, is concerned with investigating the concept of gender from a naturalistic perspective. It asks the question whether there is a relationship between determinism and gender in the two novels.

In the two novels, there is a close relation between the concept and laws of property on one hand and the perception of marriage on the other. In The Man of Property, Soames thinks that he is the legal owner of Irene, his wife who, according to his beliefs, does not the right to resist him or be wrested from him. He never respected her demand of separate rooms. When she resists him, he rapes her. This represents the climax in the narrative. Soames rapes Irene because she does not have any sexual attraction to him. Soames' act reflects the idea that he sees her as an object which he owns. He believes that his sexual abuse of her and her body does not violate rules in any way. He does not respect her privacy since her body is already owned by him. Soames does not consider his act is an invasion of the inner space of his wife and a violation of the entire female body. In the rape scene, Galsworthy describes Irene's body as vulnerable, violable, penetrable, and wounded. As the title of the novel itself suggests, Galsworthy considers Soames' sexual abuse of Irene as a brutal invasion of female sexual property. In Rape: the Price of Coercive Sexuality, Clark and Lewis (1977: 166) argue that there is a close relationship between rape culture and property concepts and laws. They indicate that adherents of rape culture see women and their bodies as a property that they own where they give themselves the "right to the exclusive ownership and control over their own bodies".

Although there are some autobiographical elements in the story, Galsworthy considers objectivity. In Novels of Everyday Life: The Series in English Fiction, Laurie Langbaur (1999: 227) argues that there are many events in the novel that are closer to Galsworthy's personal life as detailed in the relations between Irene and Bosinney on the one hand, and Irene and Jolyon on the other. He indicates that the affair of Irene and Jolyon is parallel to Galsworthy's own affair with Ada, his cousin's wife. In spite of this, Galsworthy detaches himself and considers objectivity. He does not make judgments on Irene's acts or relations. He describes her through other's eyes. Irene is described in the way men see her. However, Galsworthy's tendency towards adding elements of brutality and violence to Soames' act of rape suggest that he himself felt to some degree with sympathy towards Irene. He was psychologically influenced by Irene's sufferings. Apart from this, Galsworthy considered objectivity in his treatment of women's sufferings. He was not concerned with individuals; rather, his mind was preoccupied with some issues that needed public concern. These include the denial of women's rights as well as the absurdity and cruelty of divorce laws. So both Irene and Soames represent ideas. They are just types. They are symbols of the relationship between and women of the age. This objectivity in introducing social reality is one of the characteristics of literary naturalism.

Galsworthy also hints that rape was very frequent at the age. He discusses the issue in an objective way. However, it is like a cry against the injustice of the society towards the woman. Rape was not considered a crime at that time. Soames read in the Times about rape accidents with other sorts of crimes and accidents. The irony is that Soames was reading about rape and how surprising for him was the number of rapes, while thinking of his wife's tears and stained face. His mind could not forget "the memory of Irene's tears-stained face and the sounds of her broken heart" (Galsworthy, 1906: 484). He could not make any link between rape crimes he is reading about and his rape of his wife. This is simply because he thinks she is one of his possessions and he has the right to enjoy her beautiful body whenever he likes regardless of her opinion or wish. For him, Irene is just a beautiful body he is paying money for to get pleasure. He just thinks that lives in luxury and all her materialistic needs, so she should not be upset. He does not respect her feeling that that she lacks definitely and utterly any sexual attraction towards him. Kumar Banerjee (2007: 110) indicates that Irene, like many girls of her age, was not prepared to deal with the realities of sex. He adds that marriage, for a woman of her mentality and independent thinking, did not necessarily equate with the right to sexual relationship. "The novels also deal with the problem of female sexuality. Like other typical virgins of his age Irene was also quite unprepared to cope with the realities of sex. Moreover, to an independent mind like Irene's, marriage.

Laurie Langbauer argues that Galsworthy describes Irene-Soames relationship in terms of cause and effect which is based on Zola's (1964: 227) definition of naturalist novel. She suggests that Galsworthy relates Irene's sufferings to the problem of determinism. It is natural and external forces that determine the life of women in late nineteenth century England. In the same way, women in Palace Walk are victims of the same forces: inequality and unjust marriage/divorce customs. They are humiliated by the male patriarch who is represented in the character of Al-Sayyid Ahmad. He is a prosperous merchant who is successful in attracting customers as well as women. So he considers women as a commodity which he can buy and sell at any time. He thinks that his money enables him to buy any woman. While sitting in his shop once, Jalila, who is called the Sultana comes to get some stuff. He is very kind and generous with her and gives her the stuff for free. However they both (Al-Sayyid Ahmad and Sultana) realize that this gift is for his pleasure. Jamil Hamzawi, the shop assistant, is not pleased with the so many items she took for free and asks how this sum can be accounted for. Al-Sayyid Ahmad replies that Goods destroyed by love. The implication here 
is that the setting is a shop where Al-Sayyid Ahmad is very clever in dealing with his clients. He is a very successful merchant. So he thinks that the female body is just a commodity which he can buy and even sell.

One interesting feature in the two texts is that Galsworthy and Mahfouz dwell into the details of the female body. They show also how the beauty of women's bodies ends with examples of sexual abuse. The rationale is that the biology of women leads to her suffering in life. In this, we see women as victims of different patriarchal patterns, including biology itself. The physical beauty of Irene is attractive but she is raped and sexually abused by her husband. The body of the prostitutes in Palace Walk is highly appreciated by men who also curse the same women for the same thing. Biology then determines the sad fate of women. In his book Postcolonial Arabic Novel: Debating Ambivalence, Jasim Musawi (2003: 223) indicates that the body is a site for production of tradition. The honor of the girl and her family depends on her virginity. A girl has to observe her virginity till marriage. In this way, the woman is reduced into a single sexual organ and it is that organ that identifies the self. This reflects also the relation between gender and determinism.

Mahfouz's portrayal of women and gender relations are main reasons behind the immense popularity and large amount of attention which Palace Walk has attracted over the years. In The Social Impact of the Novel: A Reference Guide, Johnson and Johnson (2002: 4) argue that treatment of women is the dominating theme in the novel. They maintain "no other problem so permeates Palace Walk, the first novel about a Cairo family, as the Muslim view and treatment of women and the tyranny of husbands: the ability of husbands to take more than one wife, to take mistresses, to beat and mutilate their wives, to throw them out at will where they become pariahs, to forbid them from ever leaving the house, and to control their children's marriages".

Numerous, yet contradicting, interpretations have been developed in relation to the position of woman and how she was perceived by Naguib Mahfouz. Many critics insist that Mahfouz's treatment and consideration of gender is progressive indicating that he adopted an anti-patriarchal stance. On the other hand, others argue that Mahfouz represented a passive image of the woman either as a wife or even a prostitute stressing that women's rights are not assured in the novel.

In Palace Walk, Naguib Mahfouz reflects the dominance of men and the submissiveness of women in the Egyptian society during and after World War 1. It was, according to Fadwa El-Guindi (2005: 65), the most brutal period of internal patriarchy in the history of Egyptian woman. At that time, women lived in what can be described seclusion. Women were just kept at homes. Three were no employment program for women and schooling opportunities were very limited and were not free. Families had to pay for the education of their girls. One aspect of seclusion was veiling or hijab, a Muslim tradition. Women were asked to wear hijab so they cannot be seen or identified by others. A woman was only allowed to uncover her face for family members. The novel portrays women as confined to the house where they are asked to meet all the needs of men who are, in turn, free to live their lives the way they like. Mahfouz gave a true and realistic image of the wife during this period in the character of Amina. She learned by customs and traditions that her only role as a wife is to serve her husband and meet his needs. She has no right to question him or object to any of his decisions.

Mahfouz hints that Amina had nothing but to submit to her husband's will. She is always under the pressure that he can divorce her. She realizes that he married her after divorcing his first wife (Yasin's mother) and her own father had many wives. That is why, she has never objected to any of his conduct or misbehaviors. It was the rule that transferred orally from one generation to another indicating that wives have to accept their husbands as they are and agree with him whatever he was saying. In one of the dialogues between Al-Sayyid Ahmad and his wife Amina, he is telling her about the death of the Sultan and reflects his opinion about the Sultan's son position in rejecting to ascend to throne as long as Egypt is colonized by Britain. Amina has nothing to say but to agree with her husband. She cannot form an opinion herself. This is mainly because she is secluded from the society in which she lives. It is also due to the fact that she cannot oppose her husband in any way.

In spite of her obedience, however, she is thrown away for just going out once to visit Al-Hussain Mosque. The case of wives extends to prostitutes in Palace Walk. They are also dominated and humiliated by male patriarchs. Although prostitutes are represented as having a strong sexual power by which they dominate the male society, they are still marginalized since their power is very limited in scope. Worth noting, the patriarch discourse and acts of Al-Sayyid Ahmad extends to every female character in his family. It is not only his wives who are mistreated by him, his daughters as well suffer his dominance. That is why, they are eager to marry so that they will be free from their father's tyranny. The irony is that they will move from one seclusion to another. It was an entire social system where Al-Sayyid Ahmad is just a symbol.

In his description of women's problems and sufferings, Mahfouz considered objectivity and it seems that there is a sense of scientific detachment that characterizes the relation between Naguib Mahfouz and his characters. Mahfouz did not fight for women's rights. He did not also support women explicitly in their social and political struggle against the forces of society. That is why; he was blamed by many critics for not explicitly supporting woman's cause. Nawal AlSaadawi (2013) asserts that Mahfouz was never revolutionary or a reformer. She is critical of the image of the Arab woman produced by men including Mahfouz. She stresses that Mahfouz did not defend women's rights in his texts. This supports the claim that Mahfouz adopted a naturalistic attitude in his treatment of women and gender in Palace Walk. He was an objective observer who represented a reality. It may be assumed that Mahfouz was influenced by French naturalism that dominated Egyptian culture at that time. Mahfouz does not offer any resistance to the way women were treated in Cairo society. Critics also blamed Mahfouz for introducing the prostitutes as greedy women with disreputable functions (Accad, 1984). These arguments can be refuted in the sense that Mahfouz was concerned 
with the society as a whole construct, not just individuals and the characters are just types. He did not also reflect his own perceptions explicitly. He was just concerned with reality and truth without instructing or teaching his readers. In this, he follows the principles of Zola's literary naturalism. In his book Naguib Mahfouz: The Novelist-Philosopher of Cairo, Menahem Milson (1998) asserts that characters in Mahfouz's (2001) Cairo Trilogy are just fictional types who are employed by the author to serve functional roles.

In her book Gender, Nation, and the Arabic Novel: Egypt1892-2008, Hoda El-Sadda (2012: 77) criticizes Mahfouz for his representation of patriarchal practices and the oppression of women; however, she does not classify him as antifeminist. She thus claims that gender relations in Palace Walk ad Cairo Trilogy reflect a realistic picture of the age in what she calls a "national allegory". This may agree in some way to Miriam Cooke's argument of Mahfouz's treatment of gender. In "Men Constructed in the Mirror of Prostitution", Miriam Cooke (1993: 107) argues that Mahfouz could be considered a feminist writer because of his exploration of the shifting gender relations within Egyptian society during that period, and his incisive critique of masculinity within that shift, especially in the way he illuminates gender relations to be "grounded in asymmetric power". She adds that "to understand the significance of Mahfouz's female characters, we must strip away the sexist bias that has informed canonical readings and instead view his works through a feminist optic" (1993: 110). Cooke's argument supports the idea that Mahfouz did not favor the male dominance or that patriarch discourse of his hero. He was not also speaking in the name of God or Islam since these traditions do not represent Islam. He was just referring to a group of people who resist women rights and defend male tyranny in anyway. According to Fatima Mernissi (1987: ix) in her book Beyond the Veil: Male-Female Dynamics in Modern Muslim Society, “women's rights present problem for some modern Muslim men not necessarily because of the Quran or the tradition of the Prophet, both of which are subject to interpretation, nor the Islamic tradition, but simply because those rights conflict with the interests of a male elite".

It can be concluded here that both John Galsworthy and Naguib Mahfouz adopt an objective naturalist approach in their treatment of gender and the representation of women in the two texts. The two authors assume the role of observers in revealing the societal unjust laws and customs in relation to women's rights. It is also clear that there is a close relationship between gender problems and determinism. Women in Palace Walk and The Man of Property are destined to live a pessimistic determinism.

\section{Conclusion}

This study analyzed concepts of gender and determinism in John Galsworthy's The Man of Property and Naguib Mahfouz's Palace Walk. It attempted to answer the main research questions whether the two authors adopted literary naturalism in their treatment of the two concepts. In this, differences between naturalism and realism were explained. The discussions suggest that naturalism was a distinctive feature in the English novel in the late nineteenth century and the early twentieth century in spite of the fact that the term itself was invisible. As a literary movement, naturalism was linked with modernism and is considered by many critics as an advanced type of realism. The two novels Galsworthy's The Man of Property and Mahfouz's Palace Walk can be claimed to be examples of naturalistic fiction. Both Naguib Mahfouz and John Galsworthy tended their two novels to be a social realism of that given period in history. Each of the two novels is a social realism with a pessimistic determinism tone. The two authors used naturalist settings and practices as vehicles for symbolic meanings to convey thematic significance. The notions of determinism and free will and the related concepts of fate and nature are central questions in the two texts. This claim can also be supported by the idea that the two texts exhibit other naturalistic characteristics such as conflict, objectivity, pessimism, and frankness about sexual problems and issues. It should also be noted that determinism in the two texts is not religious. There is no mention of the role of God in determining the lives of his characters. Mahfouz, unlike many Arab writers, rejected the supernatural in his writings. He was even attacked for his secular beliefs by many extreme Islamists. Rejection of supernatural, according to Emile Zola, is a fundamental characteristic of literary naturalism.

The two authors also extend the notion of determinism to gender problems. In the two novels, we see that women are determined to suffer and submit to male dominance and tyranny. It is just because they are women; they are badly treated by the society. Women had nothing to do with the idea that they were born female. However, it was their destiny to pay the price for something they cannot be accounted for. We see also in the two texts how women are exploited for the female beauty. Irene in The Man of Property suffers because she is beautiful and Soames behaves in an animalistic manner with her just to satisfy his sexual needs. He refuses to divorce her because he admires her female beauty. Likewise, Prostitutes in Palace Walk are just a cheap commodity for consumers. Naguib Mahfouz represented the image of the prostitute in order to address social ills and to spot light on marginalized citizens who need help and concern just like other citizens.

Although the two authors tended their novels to be a social realism, Galsworthy included scenes of violence which can be explained that he was personally influenced by the injustice done on Irene who represents in reality Ada Galsworthy, the woman he married later after she was divorced from his cousin. Therefore, it is difficult to determine whether the two authors were progressive in adopting an explicit anti-patriarch stance. It can only be claimed that Galsworthy and Mahfouz were concerned with introducing the social problems of the age including women problems in an objective way. 


\section{References}

Accad, E. (1984). The Prostitute in Arab and North African Fiction. In P. Horn \& M. Pringle (Ed.) The Image of the Prostitute in Modern Literature, (pp. 63-75). New York: Ungar.

Allegretto-Diiulio, P. (2007). Naguib Mahfouz: A Western and Eastern Cage of Female Entrapment. Youngstown, New York: Cambria Press.

Allen, R. (1995). The Arabic Novel: An Historical and Critical Introduction (2nd Ed.). Syracuse, New York: Syracuse University Press.

Allen, R. (2006). Naguib Mahfouz: From Cairo to the World. Open Democracy 31 August 2006

Al-Saadawi, N. (1997). The Nawal Al-Saadawi Reader. New York: St. Martin's Press.

Al-Saadawi, N. (2013). Hans Ulrich Obrist in Conversation with Nawal Al-Sadawi. E-Flux Journal 42 (2): 1-11.

Ardis, A. (1990). New Women, New Novels: Feminism and Early Modernism. New Brunswick, NJ: Rutgers University Press.

Asfour, G. (1993). Naguib Mahfouz's Critics. In M. Beard \& A. Haydar (Eds.) Naguib Mahfouz: From Regional Fame to Global Recognition, (pp. 144-171). Syracuse, New York: Syracuse University Press.

Baguley, D. (1990). Naturalist Fiction: The Entropic Vision. Cambridge: Cambridge University Press.

Banerjee, S. K. (2007). Feminism in Modern English Drama: 1892-1914. New Delhi: Atlantic Publishers \& Distributors.

Barakat, H. (1993). The Arab World: Society, Culture, and State. Berkeley: University of California Press.

Beard, M. \& Haydar, A. (1993). Naguib Mahfouz: From Regional Fame to Global Recognition (1st ed.). Syracuse, New York: Syracuse University Press.

Becker, G. (1963). Documents of Modern Literary Realism. Princeton, New York: Princeton University Press.

Bell, M. (2012). The Cambridge companion to European novelists. Cambridge; New York: Cambridge University Press.

Chase, R. (1980). The American Novel and its Tradition. (British edition). London: G. Bell \& Sons.

Cooke, M. (1993). Men Constructed in the Mirror of Prostitution. In M. Beard \& A. Haydar (Eds.) Naguib Mahfouz: From Regional Fame to Global Recognition, (pp. 106-125). Syracuse, New York: Syracuse University Press.

Drinkwater, J. (1923). The Outline of Literature. (Vol. 1). London: George Newnes.

Edwards, S. (2011). The Rise and Fall of the Forsytes from Neo-Victorian to Neo-Edwardian Marriage. In M-L Kohlke \& C. Gutleben (Eds.) Neo-Victorian Families: Gender, Sexual and Cultural Politics, (pp. 197-220). Amsterdam: Rodopi.

El-Enany, R. (1993). Naguib Mahfouz: The Pursuit of Meaning. London, New York: Routledge.

El-Guindi, F. (2005). Gendered Resistance, Feminist Veiling, Islamic Feminism. The Ahfad Journal, 22 (1), 53-94.

El-Sadda, H. (2012). Gender, nation, and the Arabic novel: Egypt, 1892-2008. Edinburgh: Edinburgh University Press: Syracuse University Press.

Fleissner, J. (2004). Women, Compulsion, Modernity: The Moment of American Naturalism. Chicago: University of Chicago Press.

Frechet, A. (1982). John Galsworthy: A Reassessment. London: Macmillan.

Galsworthy, J. (1906). The Man of Property. London: William Heinemann.

Galsworthy, J. (1922). The Forsyte Saga. London: Heinemann.

Grace, D. (2004). The Woman in the Muslim Mask: Veiling and Identity in Postcolonial Literature. London: Pluto Press.

Hafez, S. (2001). Introduction to the Cairo Trilogy. London: Everyman.

Hatif, H. \& Asim, H. (2012). The Psychological and Moral Impact of Property in John Galsworthy's The Man of Property. College of Basic Education Journal, 80 (19), 839-847.

Howard, J. (1985). Form and History in American Literary Naturalism. Chapel Hill: University of North Carolina Press.

Hubble, N. (2011). In the Twentieth Century, and the Heart of Civilisation: The London of the Forsytes. Literary London Journal: Interdisciplinary Studies in the Representation of London, 9 (1)

Johnson, C. \& Johnson, V. (2002). The Social Impact of the Novel: A Reference Guide. Westport, Conn; London: Greenwood.

Joyce, S. (2014). Modernism and Naturalism in British and Irish Fiction: 1880-1930. New York: Cambridge University Press.

Keating, P. (1971). Working-Class Stories of the 1890s. New York: Barnes and Noble. 
Keating, P. (1989). The Haunted Study: A Social History of the English Novel, 1875-1914. London: Secker and Warburg.

Kohlke, M-L. \& Gutleben, C. (2011). Neo-Victorian Families: Gender, Sexual and Cultural Politics. Amsterdam: Rodopi.

Lehan, R. (2006). The European Background. In D. Pizer (Ed.). The Cambridge companion to American realism and naturalism, (pp. 47-74). Cambridge; New York: Cambridge University Press.

Mahfouz, N. (2001). The Cairo Trilogy: Palace walk, Palace of desire, Sugar Street. London: Everyman.

Margraf, E. (2005). Kate Chopin's "The Awakening" as a Naturalistic Novel. American Literary Realism, 37 (2), 93 116.

Mernissi, F. (1987). Beyond the Veil: Male-Female Dynamics in Modern Muslim Society. Bloomington: Indiana University Press.

Milson, M. (1998). Naguib Mahfouz: The Novelist-Philosopher of Cairo. New York: St Martin's Press.

Mondal, A. (2003). Nationalism and Post-Colonial Identity: Culture and Ideology in India and Egypt. London: Routledge Curzon.

Morrissey, J. (1990). A Review of the Palace Walk by Naguib Mahfouz. National Review, 26 (51).

Moosa, M. (1994). The Early Novels of Naguib Mahfouz: Images of Modern Egypt. Gainesville, Florida: University Press of Florida.

Musawi, J. (2003). The Postcolonial Arabic Novel: Debating Ambivalence. Leiden; Boston: Brill.

Nelson, B. (2012). Emile Zola (1840-1902): Naturalism. In M. Bell (Ed.). The Cambridge Companion to European Novelists, (pp. 294-309). Cambridge; New York: Cambridge University Press.

Newlin, K. (2011). The Oxford Handbook of American Literary Naturalism. New York; Oxford: Oxford University Press.

Pizer, D. (1993). The Theory and Practice of American Literary Naturalism: Selected Essays and Reviews. Carbondale: Southern Illinois University Press.

Pizer, D. (2006). The Cambridge Companion to American Realism and Naturalism: Howells to London. Cambridge; New York: Cambridge University Press.

Schalit, L. (1929). John Galsworthy: A Survey. London: Heinemann.

Sicker, M. (2001). The Middle East in the Twentieth Century. Westport, Conn: Praeger.

Sollars, M. \& Jennings, A. (2008). The Facts on File Companion to the World Novel: 1900 to the Present. New York: Infobase Publishing.

Strahan, L. (2008). Reading the Strange Silence: Irene's Acquiescence in Galsworthy's the Man of Property. University of California Riverside, 1, 6-13.

Walker, N. (1998). Feminist or Naturalist: The Social Context of Kate Chopin's The Awakening. In D. Keessey (Ed.). Contexts for Criticism. Mayfield Publishing Company.

Watson, E. (1973). The English and American Estimates of Galsworthy as a Novelist. PhD thesis. University of Arizona.

Woods, S. (1999). War of the Words: The Battle over the New Realism: Fairmont State College Occasional Papers, 11, 1-15.

Zola, E. (1964). The Experimental Novel and Other Essays. New York: Haskell House. 